\title{
Short-term study of the effect of human parietal cell antibody on the secretion of hydrochloric acid in rats
}

\author{
RENE FIASSE, IRENA BRUS, CHARLES F. CODE, AND \\ GEORGE B. JERZY GLASS
}

\begin{abstract}
From the Section of Gastroenterology and Gastroenterology Research Laboratory, New York Medical College, New York, New York, and the Section of Physiology, Mayo Clinic and Mayo Foundation, Rochester, Minnesota, USA
\end{abstract}

A very high incidence of circulating autoantibodies to parietal cells was demonstrated by Taylor, Roitt, Doniach, Couchman, and Shapland (1962), Irvine Davies, Delamore, and Williams (1962), Irvine (1963), Fisher and Taylor (1965), Irvine, Davies, Teitelbaum, Delamore, and Williams (1965), and many others in a large number of patients with pernicious anaemia and atrophic gastritis. Antibodies of this kind are also found in the anacid gastric juice of these patients (Fisher, Rees, and Taylor, 1965). An immunological mechanism responsible for the development of atrophic lesions of the gastric mucosa and gastric anacidity has been suggested (Taylor, 1963; Irvine, 1965; and Roitt, Doniach, and Shapland, 1965).

Another factor which might be contributory to the development of gastric anacidity is a depressant of gastric secretion that is found in anacid gastric juices of patients with atrophic lesions of the gastric mucosa (Brunschwig, Van Prohaska, Clarke, and Kandel, 1939). This endogenous inhibitor of gastric secretion, later called gastrone (Code, 1958), is more concentrated in the gastric juice of patients with histamine-fast anacidity than in that of normal persons. Partial purification has concentrated the activity 100- to 400-fold (Kubo, Castro-Curel, Ibanez, Glass, and Code, 1964; Fiasse, Kubo, Code, and Glass, 1966; Glass, Code, Kubo, and Fiasse, 1967; and Fiasse, Code, and Glass, 1968).

Possible relationships between the parietal cell antibodies and gastrone have not been explored. As a preliminary, the inhibitory activity of some globulin fractions from pernicious-anaemia sera was tested on pyloric secretion in rats (Glass, 1965). Some of the fractions separated on columns of DEAE-Sephadex A-50 and of Sephadex G-200

${ }^{1}$ This investigation was supported in part by research grants AM00068, AM-04391, CA-08251, AM-09701, and training grant AM05237 from the National Institutes of Health, US Public Health Service. were slightly inhibitory, but the results were not clear cut, since some fractions from normal sera inhibited the gastric secretion of acid in rats with pyloric ligation.

This study was undertaken to test the validity of those preliminary observations and to extend them by determining what effects on gastric secretion are produced by purified immunoglobulins from sera with and without parietal cell antibodies in acute experiments.

The well established cross-reactivity between the human parietal cell antibodies and the parietal cells of rats (Jeffries and Sleisenger, 1965; De Boer, Nairn, and Maxwell, 1965) causes human parietal cell antibody to react with the antigen of the rat parietal cells. Also, the inhibitory activity of gastrone may be assayed well in the rat stomach with the pylorus ligated (Menguy and Smith, 1959; Code, 1967). For these reasons, we studied the effect of human parietal cell antibodies on gastric secretion in the rat stomach.

\section{MATERIAL AND METHODS}

SERA AND THEIR SOURCES Sera were obtained from 21 patients, of whom 12 had atrophic gastritis and four of these had pernicious anaemia. Ten patients had parietal cell antibodies in their sera and 11 did not. The latter included four with peptic ulcers, two with gastric cancers, two with subtotal gastrectomies, one with portal cirrhosis, one with atrophic gastritis, and one with pernicious anaemia. Of the 10 with parietal cell antibodies, seven had atrophic gastritis, one hypothyroidism, one primary biliary cirrhosis, and one Wilson's disease. In the latter three cases, the presence of circulating parietal cell antibodies was related to the underlying hepatic (Mackay, 1964) or thyroid disease (Doniach and Roitt, 1964). The four patients with pernicious anaemia also had circulating blocking intrinsic factor antibodies in their sera.

SEPARATION OF IMMUNOGLOBULIN G (IgG) FROM SERA 9

After collection, the sera were stored separately at $-20^{\circ} \mathrm{C}$. 
Before fractionation, each was thawed and dialyzed against $0.01 \mathrm{M}$ phosphate buffer of $p \mathrm{H} \mathrm{7 \cdot 55}$. IgG was separated from the serum by the method of Vaerman, Heremans, and Vaerman (1963). After dialysis and centrifugation at $2,000 \mathrm{rpm}$, the precipitate was discarded and 1 to $2 \mathrm{ml}$ of the supernatant was applied to the top of a column ( 2 by $8 \mathrm{~cm}$ ) that had been packed with DEAE cellulose Serva and washed thoroughly with the buffer used in dialysis. The column then was eluted in a cold room with the same buffer at a flow rate of $6 \mathrm{ml} / \mathrm{hr}$. The effluent was collected in 2-ml fractions by means of a linear fraction collector provided with a volumetric counting unit. The optical density of each fraction was read at $280 \mathrm{~m} \mu$ in a DB Beckman spectrophotometer, and a graph was made to show the optical densities of all the fractions of the effluent from each serum. Since the first sharp peak of optical density is known to correspond to IgG (Vaerman et al, 1963), the fractions corresponding to this peak were then pooled, dialyzed overnight against running tap water, and lyophilized.

IMMUNOELECTROPHORESIS The purity of the IgG material obtained by this fractionation was tested by immunoelectrophoresis against antiserum to human serum. One $\mu \mathrm{l}$ of a $2 \%$ solution of this material in veronal-acetate buffer, of $p \mathrm{H} 8.6$ and ionic strength 0.05 , was put into one well of an agar plate, the other being filled with normal human serum; and both were subjected to electrophoresis with the modified Scheidegger (1955) method. Subsequently, the trough was filled with horse antiserum to human serum (Hyland) and the plate was incubated in a moist chamber for several days. After development of the precipitin lines, the plates were dried and stained with thiazine red.

ASSAYS FOR PARIETAL CELL ANTIBODIES Each serum and IgG fraction processed from it were tested for parietal cell antibodies by the modification by Taylor et al (1962) of the indirect technique of Coons. Quick-frozen specimens of normal mucosa from the human gastric fundus were cut in a cryostat to a thickness of $6 \mu$, and these sections were placed on microscope slides and fixed under dry air at room temperature. The slides were incubated for 20 minutes with the undiluted serum to be tested, and also with a $1 \%$ solution of saline of the lyophilized IgG separated from the same serum. Control slides were incubated with normal sera (not containing parietal cell antibodies). Then the slides were washed for 10 minutes in two changes of Coons' buffer. After blotting of excess fluid (except close to the section) they were incubated with one drop of fluorescinated rabbit antiserum to IgG (Hyland), washed three times in Coons' buffer, and (after blotting of the excess of buffer) mounted in $50 \%$ buffered glycerine of $p \mathrm{H} \mathrm{8.0.} \mathrm{After} \mathrm{this,} \mathrm{the} \mathrm{preparations} \mathrm{were}$ covered with cover slips, sealed with colourless nailpolish, and viewed under a Leitz fluorescent microscope provided with an Osram UV high-pressure vapour lamp.

ASSAYS FOR INTRINSIC FACTOR ANTIBODIES Assay for blocking intrinsic-factor antibodies was performed by the modified (Yamaguchi and Glass, 1967) method of Ardeman and Chanarin (1963) and Gottlieb, Lau, Wasserman, and Herbert (1965), using whole intrinsic factor inhibitory sera.

ASSAY FOR INHIBITOR OF GASTRIC SECRETION Each of the IgG samples processed on the column was sent from New York to Rochester, Minnesota, for assay of its power to inhibit gastric secretion in rats. This was done in a blind study by a method described before (Code, 1967). Rats weighing 270 to $340 \mathrm{~g}$ were fasted for 48 hours. Under light ether anaesthesia, the pylorus was ligated, the test material was injected intravenously in doses varying from 10 to $5,000 \mu \mathrm{g}$, and the rats were returned to cages designed to avoid coprophagy. After five hours, they were reanaesthetized, the cardia was ligated, and the stomachs were removed. The volume of juice in the stomach was measured, and its $\mathrm{HCl}$ content determined by an electrometric autotitrator with an endpoint of $p \mathrm{H}$ $7 \cdot 0$. The output of acid was calculated from the acid concentration and volume of gastric juice.

The fractions of IgG were given in at least three different doses to groups of three or four rats, while one group of three or four rats was given saline solution as control. From the results, a semilogarithmic doseresponse plot was made; and the quantity producing $50 \%$ inhibition was interpolated.

\section{RESULTS}

The chromatograms of the sera fractionated on the DEAE cellulose column are typified by Figure 1. A sharp peak of optical density, followed by some trailing, was obtained in each of the sera examined. When subjected to immunoelectrophoresis against the antiserum to human serum, the material contained in the sharp peak proved to be IgG. It always showed one precipitin line to $\mathrm{IgG}$, which was similar to the IgG line obtained with normal serum (Fig. 2).

The 21 sera and the IgG fractions separated from them on the column were assayed for parietal cell antibody activity. Parietal-cell antibodies were present in IgG fractions of sera containing these antibodies and not in others. The parietal cell anti-



FIG. 1. Separation of IgG from pernicious anaemia serum on DEAE-cellulose column. (O.D. = optical density.) 


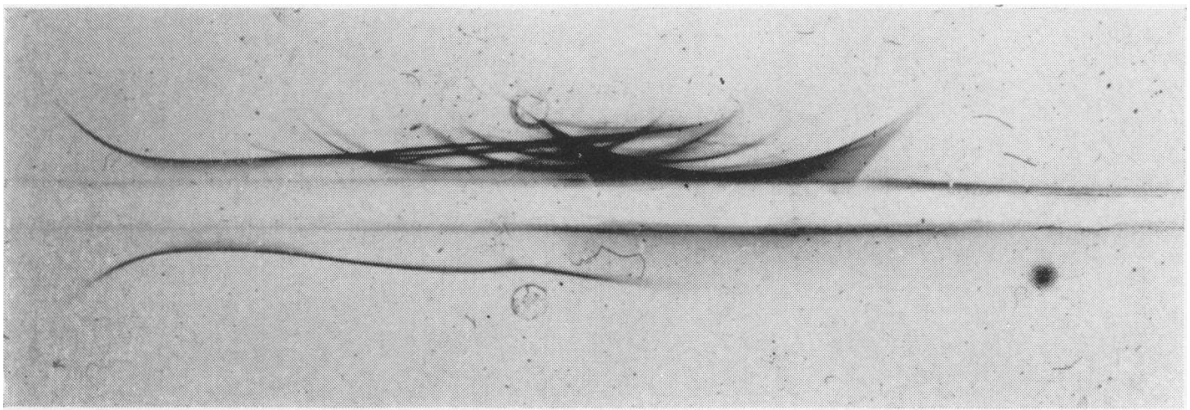

FIG. 2. Immuno-

electrophoretic pattern of serum and of $I g G$ separated from it (both containing parietal cell antibodies) run against antihuman whole serum.

bodies contained in the sera and in the IgG fractions gave positive fluorescence by the indirect method of Coons both with normal human and with rat gastric mucosa (Figs. 3 and 4).

The inhibitory activity of all the IgG fractions processed from the 21 sera was tested on rats with pyloric ligation (Table I). Seventeen of the 21 IgG fractions produced no significant inhibition in doses ranging from 10 to $1,000 \mu \mathrm{g}$ (Fig. 5 and Table I).
Slight or questionable inhibitory activity was shown by four IgG fractions at levels of 50 to $1,000 \mu \mathrm{g}$, but only one (no. 10) provided a satisfactory doseresponse curve. Furthermore, three of the four sera showing slight or questionable inhibitory activity did not contain parietal cell (Table II) or intrinsic factor antibodies, and the fourth did not contain intrinsic factor antibody. Questionable or very slight inhibition was also obtained when the dose of IgG
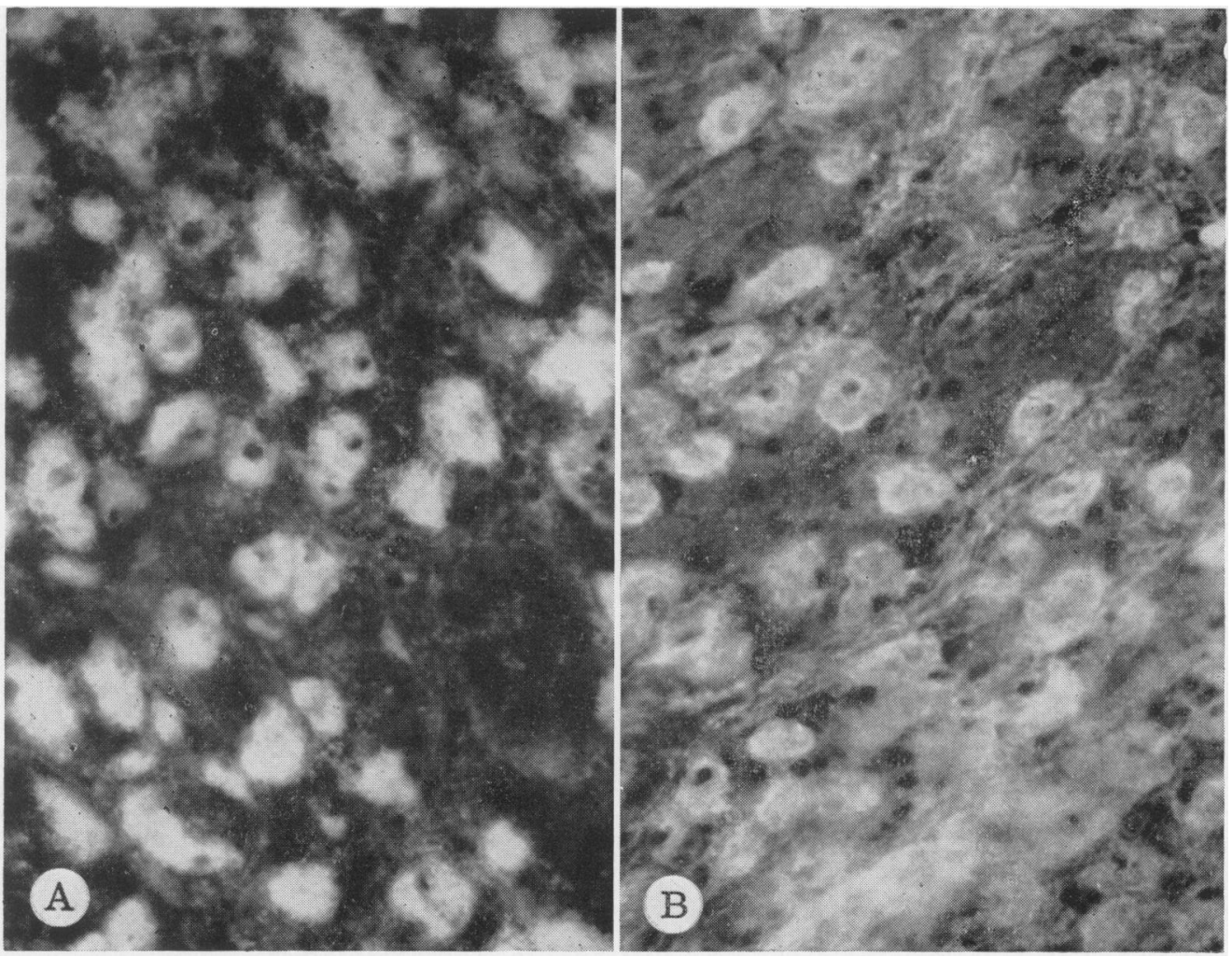

FIG. 3. A, fluorescence of parietal cells from human normal gastric mucosa after exposure to serum containing parietal cell antibody. B, similar fluorescence after exposure to IgG fraction from that serum. 

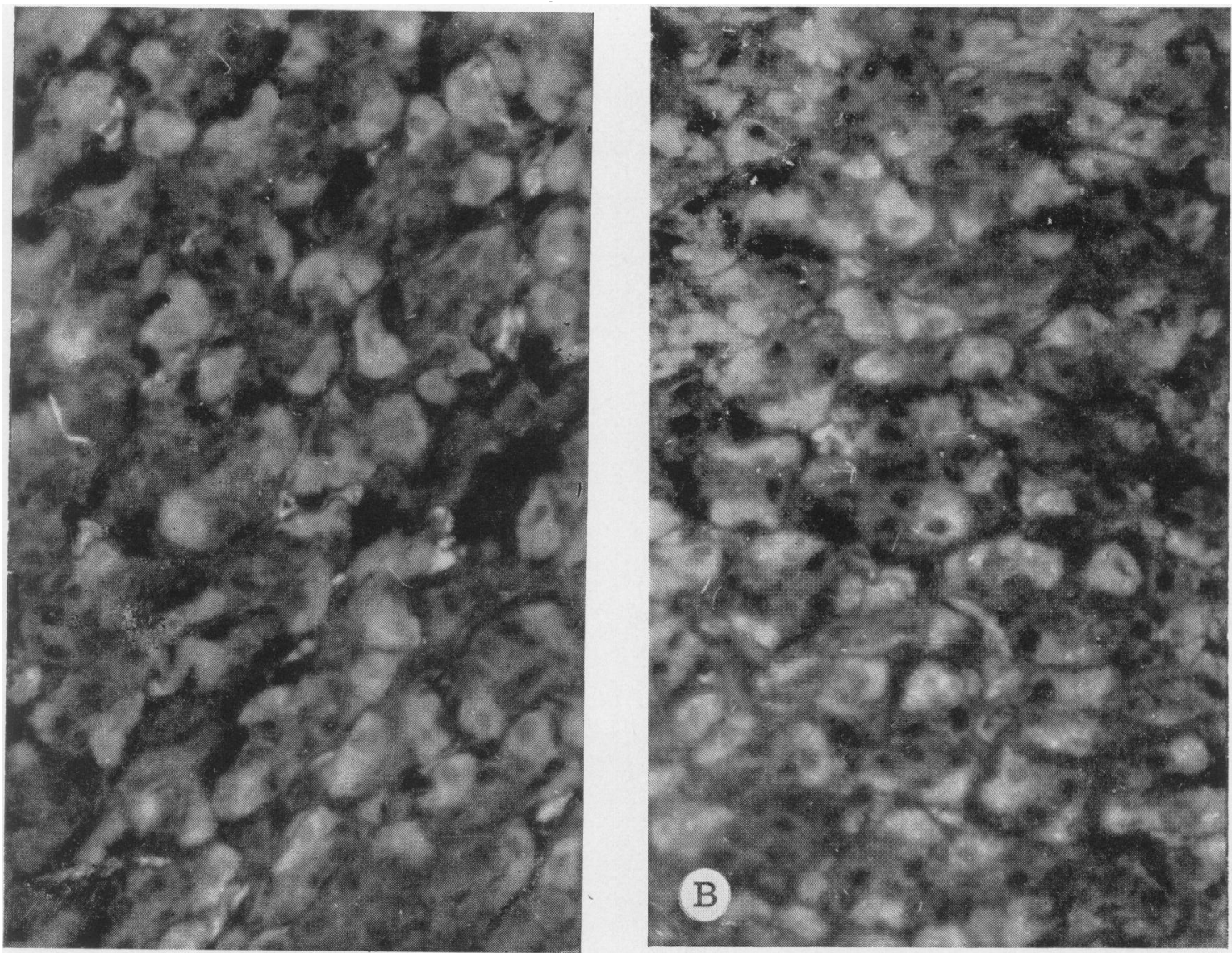

FIG. 4. Left, fluorescence of parietal cells from rat gastric mucosa after exposure to serum containing parietal cell antibody. Right, similar fluorescence after exposure to IgG fraction from that serum.

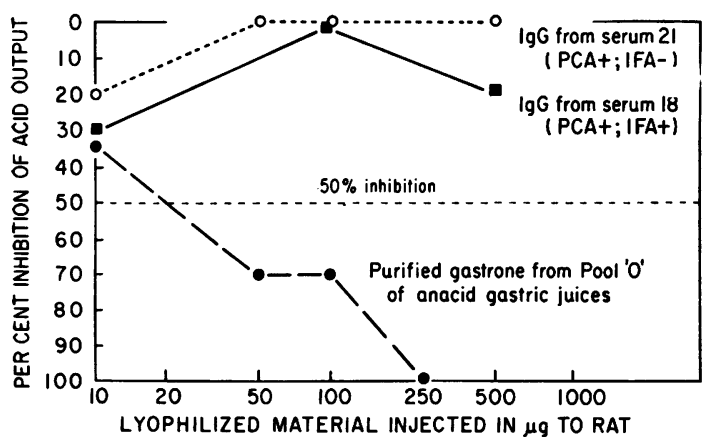

FIG. 5. Rat assay of inhibitory activity of IgG from serum compared with activity of gastrone. from parietal cell antibodies containing sera was raised up to $5 \mathrm{mg}$ (Table III).

\section{COMMENT}

After fractionation of sera containing parietal cell antibody it appeared in the IgG fraction. Yet this fraction, when injected intravenously into rats with pyloric ligation, did not inhibit gastric secretion, at least during the five-hour testing period, up to a dose of $1.0 \mathrm{mg}$. This is in contrast to the potent inhibitory effect of gastrone fractions separated from anacid gastric juice and tested under similar conditions, for they produce $50 \%$ inhibition in doses of 17 to $40 \mu \mathrm{g}$ (mean 22) (Fiasse, Code, and Glass, 1968). The lack of inhibitory activity of IgG upon gastric secretion in the rat cannot be due to a lack of the cross reactivity, for, as mentioned before, the cross reactivity between parietal cell antibody of 
TABLE I

INHIBITION OF GASTRIC SECRETION IN RATS BY IgG FROM PATIENTS WITH AND WITHOUT PARIETAL CELL AND INTRINSIC FACTOR ANTIBODIES



${ }^{1}$ Gastric secretion of acid was stimulated ${ }^{2}$ Dose $1,000 \mu \mathrm{g}$

TABLE II

RÉSUMÉ OF OVERALL INHIBITION OF GASTRIC SECRETION IN RATS BY IgG FROM PATIENTS WITH AND WITHOUT PARIETAL CELL ANTIBODIES

\begin{tabular}{|c|c|c|c|}
\hline$I g G$ from & Inhibit & Effect on Gastri & retion \\
\hline & None & $\begin{array}{l}\text { Slight or } \\
\text { Questionable }\end{array}$ & cant \\
\hline
\end{tabular}

\begin{tabular}{llll}
\hline $\begin{array}{l}\text { Without parietal } \\
\text { cell antibody (11) }\end{array}$ & 8 & 2 & $1^{2}$ \\
$\begin{array}{l}\text { With parietal } \\
\text { cell antibody (10) }\end{array}$ & 9 & 1 & 0 \\
$\begin{array}{l}{ }^{1} \text { Inadequate dose-response curve } \\
{ }^{2} \text { Carcinoma of pancreas }\end{array}$ & &
\end{tabular}

TABLE III

DIALYZED AND LYOPHILIZED IgG FROM POOLED SERA OF PATIENTS WITH POSITIVE PARIETAL CELL ANTIBODY

Fraction Dose $(\mu \mathrm{g}) \quad$ No. of Rats Percentage Change

\begin{tabular}{llll}
\hline P1 & 1,000 & 3 & -16 \\
& 2,000 & 3 & -21 \\
& 5,000 & 3 & -38
\end{tabular}

man and the rat gastric mucosa is well proved (Jeffries and Sleisenger, 1965; De Boer et al, 1965) and the parietal cell antibody contained in our IgG fractions reacted with rat parietal cells on immunofluorescence tests. Also, no evidence was obtained that blocking intrinsic factor antibody from human serum can inhibit acid secretion in rats.

Apparently, there is no significant relationship between gastrone, the endogenous inhibitor of gastric secretion, which is derived from human anacid gastric juice, and the IgG and parietal cell antibody from the serum of patients with gastric anacidity.

The limitations of our study are appreciated. To ascertain the function of parietal cell antibody in the production of gastric atrophy and anacidity will require more protracted investigation in which the effect of prolonged exposure of the gastric mucosa to parietal cell antibody is tested. This work is now in progress (Tanaka and Glass, unpublished). As yet, we have demonstrated only that parietal cell antibody at doses used in this study has no immediate effect on the secretion of gastric acid in rats in an acute experiment.

\section{SUMMARY}

The gastric secretory inhibitory activity of the IgG fractions of sera from 21 patients was tested, in rats with pyloric ligation, at doses up to $5.0 \mathrm{mg}$. Ten of the patients had parietal-cell antibodies and four of these had intrinsic-factor antibodies in their sera. The IgG fraction of one of these sera had a slight inhibitory effect on gastric secretion in the rat at the dose of $1 \mathrm{mg}$. A similarly questionable effect was obtained when $5 \mathrm{mg}$ of IgG from a pool of these sera was injected as a single dose. The IgG fraction of the nine remaining had no significant effect on gastric secretion in the rat at the dose range used in this study. None of the IgG fractions processed from four 
sera containing intrinsic factor antibodies inhibited gastric secretion in rats.

These findings were obtained in an acute experiment and do not rule out a possible long-term effect of prolonged exposure of parietal cells to circulating parietal cell antibodies.

Dr Howard Siegel, of the Gastroenterology Section of the New York Medical College, performed the gastric suction biopsies; Dr Nobuo Yamaguchi, from the same group, determined the presence of intrinsic factor antibodies; and Miss Rita Gottschalk gave valuable technical assistance.

\section{REFERENCES}

Ardeman, S., and Chanarin, I. (1963). A method for the assay of human gastric intrinsic factor and for the detection and titration of antibodies against intrinsic factor. Lancet, 2, 1350-1354.

Brunschwig, A., Van Prohaska, J., Clarke, T. H., and Kandel, E. (1939). A secretory depressant in gastric juice of patients with pernicious anemia. J. clin. Invest., 18, 415-422.

Code, C. F. (1958). Discussion. Gastroenterology, 34, 210.

(1967). The recognition and assay of gastrone. In Gastric Secretion: Mechanisms and Control. pp. 377-404. edited by T. K. Shnitka, Pergamon Press, Oxford.

De Boer, W. G., Nairn, R. C., and Maxwell, A. (1965). Pernicious anaemia autoantibody to gastric parietal cells: Immunofluorescence test with rat stomach. J. clin. Path., 18, 456-459.

Doniach, D., and Roitt, I. M. (1964). An evaluation of gastric and thyroid auto-immunity in relation to hematologic disorders. Semin. Hemat., 1, 313-343.

Fiasse, R., Code, C. F., and Glass, G. B. J. (1968). Fractionation and partial purification of gastrone. Gastroenterology, 54, 10181031.

—-, Kubo, K., Code, C. F., and Glass, G. B. J. (1966). Purification of gastrone, endogenous inhibitor of gastric secretion. (Abstr.) Ibid., 50, 842 .

Fisher, J. M., Rees, C., and Taylor, K. B. (1965). Antibodies in gastric juice. Science, 150, 1467-1469.

- and Taylor, K. B. (1965). A comparison of autoimmune phenomena in pernicious anemia and chronic atrophic gastritis. New Engl. J. Med., 272, 499-503.
Glass, G. B. J. (1965). The natural history of gastric atrophy: a review of immunologic aspects and possible links to endogenous inhibitors of gastric secretion. Amer. J. dig. Dis., 10, 376-398.

-, Code, C. F., Kubo, K., and Fiasse, R. (1967). Fractionation of endogenous inhibitor of gastric secretion (gastrone) by physicochemical means. In Gastric Secretion: Mechanisms and Control, pp. 405-425. edited by T. K. Shnitka, Pergamon Press, Oxford.

Gottlieb, C., Lau, K. S., Wasserman, L. R., and Herbert, V. (1965). Rapid charcoal assay for intrinsic factor (IF), gastric juice unsaturated B12 binding capacity, antibody to IF, and serum unsaturated B12 binding capacity. Blood, 25, 875-884.

Irvine, W. J. (1963). Gastric antibodies studied by fluorescence microscopy. Quart. J. exp. Physiol., 48, 427-438.

- (1965). Immunologic aspects of pernicious anemia. New Engl. J. Med., 273, 432-438.

-, Davies, S. H., Delamore, I. W., and Williams, A. W. (1962). Immunological relationship between pernicious anaemia and thyroid disease. Brit. med. J., 2, 454-456.

_, Teitelbaum, S., Delamore, I. W., and Williams, A. W. (1965). The clinical and pathological significance of gastric parietal cell antibody. Ann. N.Y. Acad. Sci., 124, 657-691.

Jeffries, G. H., and Sleisenger, M. H. (1965). Studies of parietal cell antibody in pernicious anemia. J. clin. Invest., 44, 2021-2028.

Kubo, K., Castro-Curel, Z., Ibanez, N., Glass, G. B. J., and Code, C. F. (1964). Fractionation of gastrone, inhibitor of gastric secretion. (Abstr.) Gastroenterology, 46, 748.

Mackay, I. R. (1964). Autoimmune serological studies in chronic gastritis and pernicious anaemia. Gut, 5, 23-26.

Menguy, R., and Smith, W. O. (1959). Inhibition of gastric secretion in the rat by normal human gastric juice. Proc. Soc. exp. Biol. Med. (N.Y.), 102, 665-667.

Roitt, I. M., Doniach, D., and Shapland, C. (1965). Autoimmunity in pernicious anemia and atrophic gastritis. Ann. N.Y. Acad. Sci., 124, 644-656.

Scheidegger, J. J. (1955). Une micro-méthode de l'immunoélectrophorèse. Int. Arch. Allergy, 7, 103-110.

Taylor, K. B. (1963). Immune phenomena in pernicious anemia. Gastroenterology, 45, 670-673.

-, Roitt, I. M. Doniach, D., Couchman, K. G., and Shapland, C. (1962). Autoimmune phenomena in pernicious anaemia: Gastric antibodies. Brit. med. J., 2, 1347-1352.

Vaerman, J. P., Heremans, J. F., and Vaerman, C. (1963). Studies of the immune globulins of human serum. I. A method for the simultaneous isolation of the three immune globulins ( $\gamma$ ss, $\gamma \mathrm{IM}$ and $\gamma \mathrm{IA}$ ) from individual small serum samples. $J$. Immunol., 91, 7-10.

Yamaguchi, N., and Glass, G. B. J. (1967). The determination of intrinsic factor in gastric secretory analysis. Ann. N. Y. Acad. Sci., 140, 924-944. 